\title{
The effect of Leucena leucocephala (lead plant) on the growth performance of catfish (Clarias gariepinus)
}

\author{
Okeke John Joseph ${ }^{1, ~}$, Ijuh Innocent ${ }^{2}$, Nwankwo Ogonna Daniel ${ }^{3}$, Arazu Vivian Nneka ${ }^{4}$ \\ ${ }^{1}$ Department of Zoology, Nnamdi Azikiwe University, Awka, Nigeria \\ ${ }^{2}$ Department of Animal Science and Technology, Nnamdi Azikiwe University, Awka, Nigeria \\ ${ }^{3}$ Department of Animal Science and Environmental Biology, Federal University, Oye-Ekiti \\ ${ }^{4}$ Department of Biological Science, Anambra State University, Uli, Nigeria
}

\section{Email address:}

okekejaja@yahoo.com (O. J. Joseph)

\section{To cite this article:}

Okeke John Joseph, Ijuh Innocent, Nwankwo Ogonna Daniel, Arazu Vivian Nneka. The Effect of Leucena Leucocephala (Lead Plant) on the Growth Performance of Catfish (Clarias gariepinus). American Journal of BioScience. Vol. 2, No. 4, 2014, pp. 111-114.

doi: $10.11648 /$ j.ajbio.20140204.11

\begin{abstract}
The efficacy of utilization of dried Leucena leucocephala leaves as a replacement of fish meal ingredient in the diet of African Catfish Clarias gariepinus of mean weight $19.00 \pm 2.00 \mathrm{~g}$ and mean length of $14.00 \pm 0.50 \mathrm{~cm}$ was evaluated for a period of 60days. The experimental diets contained Leucena leucocephala leaf meal (LLM) at levels of $0 \%$ (diet 1), 20\% (Diet2), $40 \%$ (Diet3) and 60\% (Diet 4 ) of the total dietary protein respectively. A total of 80 fingerlings were introduced into 8 aquaria of volume 40litres, each randomly assigned to the four diets $(0 \%, 20 \%, 40 \%$ and $60 \%$ LLM inclusion). Each LLM inclusion and the control had 2 replicates with 10 fingerlings in each aquarium. The following growth indices were monitored; Mean Weight Gain (WG) Percentage Weight Gain (PWG) Specific Growth Rate (SGR) and Mortality Rate (MOR). The overall result of the different growth parameters were significantly different $(\mathrm{P}<0.05)$. Fish fed with $20 \%$ LLM inclusion (Diet2) meal had the best growth performance of $42.85 \%$ and a specific growth rate of 0.25 than others. Thus the inclusion of $20 \%$ Leucenea leucocephala leaf meal in the diet of cat-fish would improve their growth and reduce the cost of production by fish farmers and if well utilized will cut down importation of fish meal in the country.
\end{abstract}

Keywords: Lead Plant, Growth, Feed Utilization

\section{Introduction}

Fish farming continues to make substantial contribution to Nigeria's animal protein requirement. Globally, there has been an increased in the production by weight of fish, crustateans and molluska from $3.9 \%$ in 1970 to $27.1 \%$ in 2000 and to $32.4 \%$ in 2004 (FAO, 2006). Nigeria's contribution to these global figures remain largely insignificant. Hence, there is need to bridge the yearning gap.

The major setback in fish farming business is the challenge farmers face with fish feed. It is either imported largely or formulated locally to meet the demand. The most preferred species of fish reared locally in Nigeria is the African Cat fish (Clarias gariepinus) and Tilapia (Oreochromis niloticus) and are consumed much due to the quality of its flesh. (Pruszyriski, 2003). They are often smoked and used in our dishes.

The African Catfish is Omnivorous, grows fast and tolerate relatively poor water quality, therefore it is an excellent species for aquaculture. (Rad, et al., 2003). Aquaculture plays a very vital role in providing affordable high quality protein all around the world. Fish provides not only protein, but also a balance amino acid, rich vitamins and minerals. They contain polyunsaturated fatty acid when much are required in the development of the brain and provide energy, dense fatty acids for infant who may be unable to derive energy from a predominantly cereal based diet (Edwards, 1997).

Leucenea leucocephala leaves (lead plant) is a leguminous plant which was originally found in Mexico and has a relatively high nutritive value and can make contribution to fish nutrition with the possibility to reduce the total dependence of fish farmers on fish meal in several locations in Nigeria. (FIRA, 1980)

Leucenea leucocephala also provides wood for fuel, 
green manure to improve degraded lands and can be used as cover crops. The leaves are known to contain about $22.7 \%$ crude protein (Atawodi et al., 2008) and survives well on degraded soil which are low in nutrients. Leucenea leucocephala is available in almost every geographical location and grows fast, especially in Ghana.

The high cost of fish meal makes commercial production of catfish capital intensive as it account for between 30\% to $60 \%$ of variable operating cost (Desilva and Anderson, 1995). This has motivated for the search for local cheap alternative source of protein that will reduce production cost without compromising fish quality.

\section{Materials and Method}

\subsection{Experimental Site}

The study was conducted at the Fisheries and Aquaculture unit of the Department of Zoology, Nnamdi Azikiwe University, Awka, in Awka South Local Government Area of Anambra State, Nigeria.

\subsection{Experiment Design}

The experiment was conducted using 8 plastic transparent aquaria of volume 40litres, each, containing 35 litres of water respectively. This level of water was maintained throughout the eight weeks of the experiment. Eighty fingerlings of Clarias gariepinus of homogenous size were used for the study. They were stocked at a density of 10 fingerlings per aquarium randomly. These fingerlings were obtained from Awka fish farm and were acclimatize for one week in the aquarium and were feed with the formulated feed.

\subsection{Fish Feed Formulation and Feeding}

The constituents of the experimental feed were; fish meal, soya beans meal, corn meal, wheat offal, vitamin and mineral premix, oil, salt. Leucana leucocephala were collected, identified, air dried at room temperature and grund using Hammer machine. The feeds were prepared separated according to the level of LLM inclusion $(0 \%$, $20 \%, 405$ and 60\%). The different component were weighed out separately and thoroughly mixed, pelleted into $2 \mathrm{~mm}$ size, sundried and stored at room temperature to avoid spoilage .Fish were fed twice daily at 8.00am and $7.00 \mathrm{pm}$ throughout the period of the study.

\subsection{Performance Indices / Parameter}

\subsubsection{Weight of the Fish / Length}

The weights of the fish (fingerlings) were determined by the use of a Digital Weighing balance and recorded to the nearest $0.00 \mathrm{gm}$. The weight gain of the fish (fingerlings) were obtained by the difference between the mean total weight and the mean initial weight divided by the difference between the total number of days the experiment lasted. While the lengths of the fish were obtained by the use of a meter rule and recorded to the nearest $0.00 \mathrm{~cm}$.

\subsubsection{Indices of Feed Utilization}

Performance parameters monitored were Weight gain (WG), Percentage weight gain (PWG), Specific growth rate (SGR), Mortality rate (MOR)

\subsubsection{Chemical Analysis of Water}

The Physio chemical Analysis of water was determined through the study period. The temperature of water was taken by the use of Mercury- in- glass thermometer and the value recorded. The $\mathrm{pH}$ of water was also measured by using $\mathrm{pH}$ meter. Dissolved oxygen in the water used for the study was also obtained by the use of Winkler method to ascertain the volume of oxygen present in the water used for the study.

The mathematical representation of the growth performance indices is shown below:

$$
\begin{gathered}
\mathrm{WG}=\frac{\text { final weight }- \text { initial weight }}{\text { Time }(\text { final }- \text { initial })}=\frac{\mathrm{W}_{1}-\mathrm{W}_{2}}{\mathrm{~T}_{1}-\mathrm{T}_{0}} \\
\mathrm{SWG}=\frac{\mathrm{W}_{1}-\mathrm{W}_{0}}{\mathrm{~T}_{1}-\mathrm{T}_{0}} \times \frac{100}{1} \\
\mathrm{SGR}=\frac{\log ^{\mathrm{eW}} \mathrm{W}_{1}-\mathrm{Log}_{\mathrm{G}} \mathrm{W}_{0}}{\mathrm{~T}_{1}-\mathrm{T}_{0}} \times \frac{100}{1}
\end{gathered}
$$

$\mathrm{W}_{1}=$ Final weight

$\mathrm{W}_{0}=$ Initial weight

$\mathrm{T}_{0}=$ Initial time

$\mathrm{T}_{1}=$ Final time

$\log ^{\mathrm{e}}=$ Natural $\log$

$$
\text { Mortality }=\frac{\mathrm{N}_{0}-\mathrm{N}_{\mathrm{e}}}{\mathrm{N}_{0}} \times \frac{100}{1}
$$

$\mathrm{N}_{0}=$ Number at the start of experiment

$\mathrm{N}_{\mathrm{t}}=$ Number at the end of experiment

\subsubsection{Chemical Analysis of Feed}

Proximate analysis was carried out for dry matter content crude protein, crude fibre, crude lipid, ash coal, Nitrogen extract using the method invented by the association of officiating analysis (AOAC), 1991.

\subsubsection{Statistical Analysis}

Data collected from feed utilization indices were subjected to Analysis of Variance (ANOVA). Difference among the treatment means were separated using the least significant differences (LSD) at 95\% confidence limit.

\section{Result}

Table1 shows the range of physic chemical analysis of water that was used in the experiment. The parameters are temperature, $\mathrm{pH}$ and Dissolved oxygen. 
Feed composition parameters are presented in Table2. Results of proximate analysis for Leucana leucocephala use for growth of Clarias gariepinus for eight weeks are presented in Table3. While the feed utilization parameter of the cat fish fed on partially substituted diet with ranging levels of Leucana leucocephala leaves are presented in Table4.

Growth performance indices of African catfish fed on the diet treatment $\left(D_{1}, D_{2}, D_{3}, \& D_{4}\right)$ are presented in Table5. Table 6 represents the statistical analysis of variance (Anova) of the means at 5\% level of significance. The growth performance parameters shows that catfish feed on partially substituted level of Leucana leucocephala leaves at $20 \%$ inclusion had the highest performance. Mean weight gain or increase during the experimental period while those fed on $60 \%$ rate had the lowest performance mean weight gain / increase. It then means that treatment with $20 \%$ inclusion had the highest percentage weight gain of $42.85 \%$. The least had (60\% inclusion) $29.41 \%$, next to the highest is diet 1 ( $0 \%$ LL inclusion) with $35.85 \%$ and diet 3 (40\% LL inclusion) with $33.33 \%$. The specific growth rate follow the same pattern as that of the percentage weight gain, diet $2(0.25)$ had the highest, while diet $4(0.19)$ had the least. The percentage weight gain was significantly different $(\mathrm{p}<0.05)$ among the diet $(1,2,3, \&$ $4)$. There was no record of mortality rate of the catfish among the various diet in the experiment conducted

Table 1. Range of some water in the experimental tanks

\begin{tabular}{lll}
\hline $\mathbf{S} / \mathbf{N}$ & Water quality parameters & Range \\
\hline 1 & Temperature & $26.50-27.50^{\circ} \mathrm{c}$ \\
2 & PH & $6.80-7.30$ \\
3 & Dissolved oxygen & $3.00 \mathrm{mg} / 1-4.50 \mathrm{mg} / 1$ \\
\hline
\end{tabular}

Table 2. The Feed Composition Ratio

\begin{tabular}{lllll}
\hline Ingredient & $\mathbf{0 \%}$ LL Inclusion & $\mathbf{2 0} \%$ LLM Inclusion & $\mathbf{4 0 \%}$ LLM Inclusion & $\mathbf{6 0 \%}$ LLM Inclusion \\
\hline Fish meal & 30 & 24 & 18 & 12 \\
LLM & 0 & 6 & 20 & 18 \\
Soya beans meal & 20 & 20 & 15 & 20 \\
Corn meal & 15 & 15 & 15 & 15 \\
Wheat offal & 15 & 15 & 15 & 15 \\
Wheat flour & 15 & 15 & 1 & 1 \\
Bone meal & 1 & 1 & 1 & 1 \\
Vitamin premix & 1 & 1 & 1 & 1 \\
Mineral premix & 1 & 1 & 1 & 1 \\
Vegetable oil & 1 & 1 & 1 & 1 \\
Salt & 1 & 1 & 100 \\
Total & 100 & 100 & 1 & 1 \\
\hline
\end{tabular}

Table 3. Proximate composition of LLM used for the growth

\begin{tabular}{lllll}
\hline Parameters & LLM 0\% & LLM 20\% & 40\% LLM & 60\% LLM \\
\hline Crude protein & 37.40 & 38.11 & 37.75 & 37.22 \\
Crude lipid & 10.63 & 11.29 & 12.15 & 12.33 \\
Crude fibre & 3.35 & 4.80 & 4.85 & 5.82 \\
Ash & 9.18 & 9.15 & 9.15 & 9.13 \\
Nitrogen free extract & 39.44 & 36.65 & 36.08 \\
\hline
\end{tabular}

Table 4. Summary of weight gain of African catfish fed with different levels of Leuceana leucocephala for eight weeks

\begin{tabular}{|c|c|c|c|c|c|c|c|c|c|}
\hline Diet & Week 1 & Week 2 & Week 3 & Week 4 & Week 5 & Week 6 & Week 7 & Week 8 & Weight gain \\
\hline $0 \%$ LLM & 20.00 & 21.40 & 22.00 & 23.01 & 24.50 & 25.03 & 26.01 & 27.00 & 7.00 \\
\hline $20 \%$ LLM & 21.00 & 22.05 & 23.04 & 24.08 & 26.00 & 27.02 & 28.01 & 30.00 & 9.00 \\
\hline $40 \%$ LLM & 18.00 & 18.50 & 19.80 & 20.70 & 21.50 & 22.04 & 23.20 & 24.00 & 6.00 \\
\hline $60 \%$ LLM & 17.00 & 17.60 & 18.01 & 18.70 & 19.50 & 20.70 & 21.50 & 22.00 & 5.00 \\
\hline
\end{tabular}

Table 5. Growth performance indices of African catfish fed on different diets

\begin{tabular}{|c|c|c|c|c|}
\hline Parameters & $D_{1} 0 \%$ LLM & $D_{2} 20 \%$ LLM & $D_{3} 40 \%$ LLM & $D_{4} 60 \%$ LLM \\
\hline Mean Weight gain \pm 1.00 & 7.00 & 9.00 & 6.00 & 5.00 \\
\hline Percentage weight gain $(\mathrm{PWG}) \pm 0.05$ & 35.00 & 42.85 & 33.33 & 29.41 \\
\hline Specific growth rate (SGR) & 0.22 & 0.25 & 0.21 & 0.19 \\
\hline Mortality rate & 0.00 & 0.00 & 0.00 & 0.00 \\
\hline
\end{tabular}


Table 6. Shows the statistical analysis of variance of the means at $5 \%$ level of significant

\begin{tabular}{llll}
\hline Inclusion Rate & Weight gain & Percentage Weight Gain & Specific Growth Rate \\
\hline 0\% LLM Inclusion & 23.630 & 18.150 & 0.700 \\
20\% LLM Inclusion & 25.150 & 19.760 & 0.763 \\
40\% LLM Inclusion & 20.970 & 16.490 & 0.549 \\
$60 \%$ LLM Inclusion & 19.290 & 13.490 & 0.410 \\
LSD (0.05) & 0.628 & 2.358 & 0.109 \\
\hline
\end{tabular}

\section{Discussion}

Growth performance of the African cat fish feed with varying quantity of feed containing Leucena leucocephala leave meal over 56days period is presented in Table5 above. Fish in all the above diet (Diet 1, 2, 3, \& 4) indicate a significant different $(\mathrm{P}<0.05)$ in growth. The proximate composition of the four experimental treatment proved that it contained adequate protein and good level of fibre and lipid content for the proper growth and development of the catfish as in Igwebuike et al (2010).

There was slight variation in the composition among the formulated diet as the inclusion of Leucena leucocephala meal (LLM) increased, the fish meal content decreased.

The decrease in fish meal and increase in Leucena leucocephala meal may be caused by the increase in crude protein content at 20\% inclusion (Diet 2). This scored diet 2 has the best inclusion rate.

Further increase in the inclusion rate $(40 \%, 60 \%)$ result in a decrease in the crude protein content of the diet. It was also observed that the $20 \%$ inclusion of LLM in diet 2 results also to an increase in the crude lipid, crude fibre, content, while there was a decrease in Ash content and Nitrogen extract. See Table 3 above, diet 2 had the highest growth performance while diet 4 (60\%LL inclusion) had the least growth performance of the African catfish within the 56days periods.

The lowest growth response by the fish fed with $60 \%$ LLM inclusion diet was probably caused by reduced palatability of the diet, which led to reduced feed intake. The highest growth response by fish fed with diet $2(20 \%$ LLM inclusion) may be due to the increase in crude protein, crude lipid and crude fibre content in the meal. The palatability may have contribution with the decrease in crude protein, ash content, and Nitrogen extract of diet3 (40\% LLM inclusion) and diet 4 (60\% LLM inclusion) respectively.

In the feed utilization indices in Table5 Diet2 (20\% LLM inclusion) had the highest percentage weight gain $(42.85 \%)$ and specific growth rate $(0.25)$, while diet4 (60\% LLM inclusion) had the least percentage weight gain of $35 \%$ and $33.33 \%$ respectively, then their specific growth rate were 0.22 and 0.21 respectively. The anti-nutritional facto level in LLM diet increased with inclusion level of LLM.
The physio chemical parameter of water used in this study were within the range for culturing Clarias gaiepinus and this is similar to the findings of Boyd 1979; Mazik et al 1991. The overall result of the growth indices were significantly different $(\mathrm{P}<0.05)$ among the diets.

\section{Conclusion}

The leaves of Leucena leucocephala have the potential of making considerable contribution to the growth of the African catfish. It also has the potential to partially replace fish meal in a feeding regine and thereby reduce cost for fish farmers whose most important production cost goes to feed. This study has demonstrated that Leucena leucocephala meal could be included up to $20 \%$ level in Clarias gariepinus diet and therefore suggest the percentage as the optimum requirement for catfish growth performance.

\section{References}

[1] Atawodi: S.E. Mari, D., Atawodi, J.C. and Yahaya, Y.(2008). Assessement of Leucasana leucocephala Leave as feed supplement in laying hens. African Journal of Biotechnology Vol.7 (3) PP. 317-321

[2] Boyd, C.E., (1979). Water quality in warn water fish ponds Auburn University Agriculture Experiment Station, Auburn, Alabama.

[3] Edwards, P. (1997) sustainable food production through Aquaculture. Aquaculture Asia 2 (1):4-7

[4] FAO, (1996), World Food Summit Plan of Action. Food and Agriculture Organization of the United Nations, Rome, Italy.

[5] Mazik, P.M., M.L. Hinman, D.A. Winkleman, S.J. Kleine, B.A.Simco.(1991). Influence of nitrate and chloride concentration on survival and hematological profile of striped bass transactions of the American Fisheries society, 120:247-254.

[6] Pruszynski, T.(2003). Effect of feeding on ammonium excretion and growth of the African catfish (Clarias gariepinus) fry. Czech J. Anim. Sci., 48 (3): 106-112.

[7] Rad, F., Kurt, G.I., and Bozaoulu, A.S (2003) Effect of spatially localized and dispersed pattern of feed distribution on the growth, size dispersion and feed conversion ratio of the African Catfish (Clarias gariepinus). Turk J Vet Anim Sci 28, 851-856. 